PRESIDENTIAL ADDRESS

\title{
Devolution and the Evolution of Regional Science
}

\author{
Judith I. Stallmann*
}

\begin{abstract}
Devolution is an institutional issue with several dimensions-space, ownership, and time. Because it has a spatial dimension, regional scientists are well positioned to contribute to the devolution debate. The transition from public to private ownership can create incentives for corruption. To address transitions we will need to draw on sociology and political science. Because they are more centralized, southern states may be less institutionally equipped to handle devolution than other states. Rural local governments are also less equipped than urban governments to handle devolution. Regional scientists can assist local governments with analysis and training.
\end{abstract}

\section{INTRODUCTION}

Several things came up recently that got me thinking about devolution. While teaching in Nicaragua and Guatemala last year, I got some questions about privatization. Guatemala had sold the telephone company. Nicaragua was going to and then didn't for some reason that I did not understand. Then came the revelations about Helmut Kohl accepting money from businesses as the economy of the former East Germany was being privatized. This started me thinking about devolution, the process of devolution, and the role that regional scientists might play.

\section{FRAMEWORK}

I will use "devolution" to include both decentralization of government and privatization. Clearly devolution is an institutional issue, but to understand it I break it into three dimensions (Figure 1).

Decentralization is a spatial term. It means moving things out from a center. In the United States, as in all countries, governments have a geographic location. Decentralization of government means moving the decision making to other governments, which have geographic locations different from that of the central government, or to the people, who are even more geographically dispersed. Because decentralization has a spatial component, there is a role for regional scientists in the debate.

Privatization concerns the change of ownership and, therefore, decision making. Ownership is a property right, and most property rights are a bundle of

\footnotetext{
*Associate Professor and Extension Economist, Department of Agricultural Economics, Texas A\&M University. Presented as the Presidential Address at the annual meeting of the Southern Regional Science Association, Miami Beach, Florida, April 2000. I would like to thank Steve Deller, Dennis Fisher, Eluned Jones, Lonnie Jones, Linda Radzik, Al Schmid, and Bob Shandley for their insightful discussions with me on this topic.
} 
rights (Hirsch 1979). Thus, there are many alternative institutional forms that ownership can take.

FICURE 1

Factors Affecting Devolution

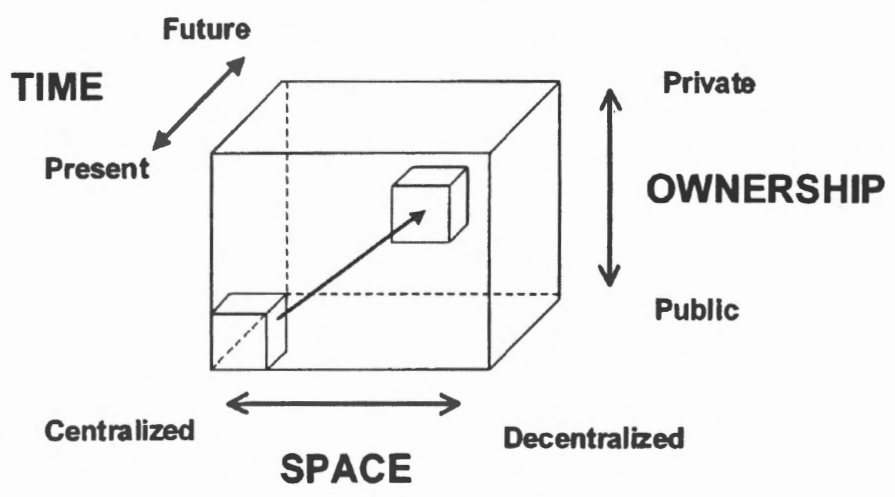

The "de" in both decentralization and devolution means a change from one way of doing something to another. That is, the concept includes time.

Thus I conceptualize devolution as including three factors. I portray them using a diagram similar to that used by Johnson (1994) in his presidential address. There are three axes: 1) space, which moves from centralized to decentralized; 2 ) ownership, which moves from public to private; and 3) time, which moves from the present to the future. What I want to do is look at these three components of devolution and the opportunities and challenges they provide for regional economists.

\section{DECENTRALIZATION}

My definition of decentralization focuses on moving the locus of decision making to a lower level of government, or to the people.

\section{Deconcentration}

Deconcentration-moving the physical location of bureaucracies or institutions, as is occurring in Canada at both the national and provincial level-is a form of decentralization. In the United States, state and federal regional offices are examples of deconcentration. While the objective is the geographic dispersion of activity, the simple geographic transfer out from the center includes, as a byproduct, the transfer of some decision-making control. Any parent with a teenager experiences this whenever the household "deconcentrates" by the teenager leaving the house. Some decision-making control also leaves the house.

Deconcentration is something that the private sector has been doing for years. All regional scientists are familiar with branch plants, a form of deconcentration. The movement of firms and plants has impacts on losing and receiving regions. Deconcentration of government results in impacts similar to the impacts of plant openings and closings, which regional science has been addressing for years. Regional scientists are also versed in the use of location models to address the optimal location of government offices. 


\section{Decentralization to State and Local Government}

Decentralizing moves the control of decision making to a lower level of government. The arguments for decentralization center on the potential for cost savings and increased quality from putting the service closer to the control of those receiving it. Improved performance is expected from programs being better designed to meet local needs rather than being one-size-fits-no-one programs (Garkovich and Irby 1998; Luttbeg 1999).

Decentralization results in the closing, or shrinking, of some bureaucracies and the opening of other bureaucracies. As I noted above, regional scientists have a long history of looking at the impacts of a specific geographic location. Even more important, however, are the issues of decreased costs and improved performance. Regional scientists can compare the costs of offering the services in a centralized system versus a decentralized system. Regional scientists also have an opportunity to evaluate the changes in performance as a result of decentralization. In one project that I am aware of, regional scientists are looking at the impacts of the decentralization of our national welfare system on rural residents (Reinschmiedt et al. 1999).

Another opportunity for regional scientists is in the area of determining good candidates for decentralization. The public finance literature suggests that jurisdiction should fall to the level of government that encompasses the costs and benefits of the actions. In the case of jurisdictional spillovers-basically geographic externalities - the activity should be placed at the level of government that includes all the jurisdictions affected (Stiglitz 1988). While that is what the theory suggests, it is easy to find cases that do not follow that rule. For example, the Environmental Protection Agency has fewer powers in the areas of air and water, which clearly have jurisdictional spillovers, than it does with respect to Superfund sites, whose impacts are much more localized (Donahue 1997). In addition, the public finance literature makes a strong case for maintaining equity programs at higher, rather than lower, levels of government. Yet we recently decentralized our national welfare program. Clearly there is a role for regional economists in setting criteria for decentralization.

While decentralization is the current hot topic, there are plenty of instances of the opposite also occurring, ranging from common markets among countries to consolidation of school districts (Deller 1998). We apparently have forces working in both directions, another potential area of research for regional scientists.

We also have to consider boundary issues. States and local governments have geographic boundaries. Boundaries affect whose choices count. That is why the current Census has been so contentious. Congressional redistricting affects who holds power-whose choices count. This is also why the issue of school district or local government consolidation is contentious.

A second boundary issue is that decentralization allows each government to make decisions that differ from its neighbors (Figure 2). These differences create incentives for people and firms to respond in various ways. The concern that 
FIGURE 2

Neighbors' Alternative Choices and Paths of Devolution

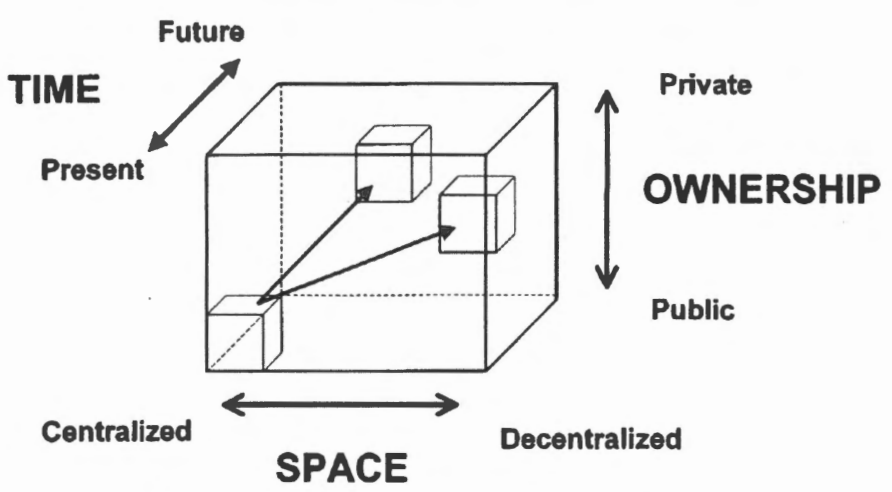

welfare reform might lead to a "race to the bottom" is an expression of this idea. (As cited in Donahue (1997), Justice Brandeis used this term in 1933 when expressing concern about state chartering of multistate corporations.) Is this likely? It will, of course, depend in part on the degree of control the federal government exercises. An examination of state policies on gambling would suggest that a "race to the bottom" is possible (Donahue 1997). State and local incentives for firm location appear similar. On the other hand, California has maintained environmental policies very different from its bordering states. When does a race to the bottom result, and when does it not? In a review article, Oates (1999) suggests that the jury is still out. This is an area to which regional scientists can contribute.

I have heard regional scientists lamenting decentralization because each state would have its own program with different criteria and different data, making research difficult. We as regional scientists have always recognized differences among regions, so we may be better prepared than others to deal with this. Our local economic and fiscal impact models already deal with the fact that states are different. We have all heard of the states as "laboratories of democracy" (Brandeis as quoted in Donahue 1997), and using quasi-experimental designs we can evaluate alternative ways of providing a good or a service (Cook and Campbell 1979).

If the states are "laboratories of democracy," what happens if an experiment fails? What is the role of other levels of government if it does? Some states are looking at data issues (Walton and Kraushaar 1990). Maybe we can build on the model of the state data centers, which is a cooperation between the states and the federal government for data collection and dissemination. Maybe our role is to emphasize the importance of data and to help states define concepts for measurement and how to measure them. We can also provide analysis and training about the use of data to local governments (Brown and Glasgow 1991; Garkovich and Irby 1998).

It is also worthwhile to consider that we have ignored differences among states in the past, so that our data may not measure what they purport to measure. For example, the difference between states in the duties and responsibilities of local governments means that the categories in the Census of Government are not 
measuring the same thing across states. Nelson and Braschler's (1995) work on Medicare and Medicaid shows that those data do not measure what they purport to. Maybe data will become more accurate when we do not try to make one-sizefits-all categories.

When doing research it is often useful to look for parallels elsewhere. In addition to deconcentration, Canada has decentralized by creating a new, semiautonomous territory. While the U.S. government is more decentralized than most, Canada is even more decentralized (Dion 1995). For researchers in the U.S., it is worthwhile to look at the Canadian experience.

The rise of the ".com" companies is an example of decentralization in the private sector. There is new literature in management about the control and performance of these companies (Barsness 1999 is an example). That research may be a useful starting point when looking at the performance of decentralized government.

\section{Decentralization to the People}

The ultimate decentralization is decentralization to the people. The tenth amendment to the U.S. Constitution states, "The powers not delegated to the United States by the Constitution, nor prohibited by it to the States, are reserved to the States respectively, or to the people." Vouchers are an example of decentralization to the people (Gromley 1995). Why do we accept food stamps and WIC coupons, but school vouchers are contentious? Why don't we have medical care vouchers? The Johnson administration ran some interesting experiments on some of these programs. It may be time to revisit the evaluations of those experiments (Haveman 1987; U.S. Department of Health, Education, and Welfare 1976). They may be relevant for current policy proposals.

\section{PRIVATIZATION}

As I noted at the beginning, there is a wide range of ownership options available. The continuum of ownership goes from government, to nonprofit, to for-profit with no special government oversight. In between we have publicprivate partnerships, for-profit and nonprofit partnerships and alliances, contracting, monitoring, regulation, etc. These are not new ideas to regional scientists, who see local and state governments entering into many types of relationships with the private sector, especially to attract business or build sports stadiums.

\section{Privatization of Publicly Owned Capital or Assets}

Much of the literature on privatization is about the privatization of publicly owned enterprises. This literature focuses mainly on Eastern Europe and the Former Soviet Union. There is also some literature on Great Britain during the Thatcher period.

A recent survey of the Council of State Governments found that threefourths of the states have no standardized process for determining which activities will be privatized (Chi 1998). Another role for regional scientists is helping states and local governments set criteria for privatization. 
The literature on privatization focuses on cost savings. Improved performance, per se, is not prominent in the literature. But incentives for cost savings may also be incentives for cutting quality (Schmid 2000). In addition, government programs often have multiple objectives (Deller 1998). For example, in the Soviet Union and China, the enterprise was often the source of education, health care, and old age security for the workers and their families. But what happens to these other objectives when the enterprise is privatized? Talking about the increased efficiency of the enterprise seems to miss a good deal of the issue.

When evaluating cost savings we need to ask: Are we providing the same service, or are we providing a different service, per the Soviet Union and China examples that I gave earlier? Are we reaching a different clientele? If a new monitoring institution is set up, should the costs of that institution be included? Public sector bookkeeping is different from that of the private sector, particularly in the valuation of assets. How do you reconcile the two (Chi 1998)? The argument is that the enterprise or the services will become more efficient. Yet 62 percent of states said their cost savings were less than 5 percent (Chi 1998).

Deller (1998) points out that the studies of cost savings from privatization are a biased sample. What gets privatized are mainly those activities where the private sector can show a cost savings. Where it cannot, the function is not privatized. He also points out that in some cases, companies have failed and turned the activity back to government. In our rush to privatize we seem to forget history. Yes, the world has changed and there may be good reason to revisit the issue, but an analysis of past failures may be a useful starting point.

Replacing a public monopoly with a private monopoly changes very little, and gives a private firm control over a major asset or service. Yet in the example of the privatization of the Guatemala telephone system that I mentioned above, a public monopoly was traded for a private one. Many countries are doing the same with their phone systems. It is also my observation that governments seem to prefer a contract with a single firm rather than multiple firms. Why is that, or is my observation biased?

What happens to costs and to performance when we change to organizations that have different objectives? We know that for-profit entities have a profit objective, a different objective from that of the government institution. The nonprofit organization has an objective of providing service to a target population. If the nonprofit is budget constrained, as many are, it may be a cost minimizer. A research question is whether nonprofits or for-profits will do better in certain arenas.

\section{Privatizing Operations}

Miranda and Lerner (1995) point out that there are many options for achieving the cost savings that are supposed to come from privatizing, short of selling the public asset or enterprise, such as contracting for the management of government assets. Management can be contracted to a private firm with govern- 
ment auditing and oversight. The government might contract individual consultants for a specific project who report directly to a government employee. The government might contract parts to different organizations, both for-profit and nonprofit. There is also the possibility of contracting with both the public and the private sectors (Gromley 1995). A public firm in an industry dominated by the private sector may keep the private firms honest, and vice versa. As researchers, we can evaluate the outcomes of alternative institutional arrangements. In that research we must remember that government is not concerned just with efficiency, as we are in danger of forgetting that when we focus just on the cost savings of privatization (Deller 1998).

If the privatization is at the managerial and/or professional level, it is likely that costs will rise, because salaries at this level are higher in the private sector. In Texas, engineering costs for transportation projects have increased substantially with the contracting of private engineers. In this case, the cost difference could not be attributed to quality differences between the public and private sectors because the consultants were the former public employees (Feldman 1999). At other levels of employment will the cost savings from privatization come from paying less than union wages (Schmid 2000)? If so, there is a distributional issue of who loses and who benefits from privatization that needs investigation. A further area of investigation concerns the role of legislatively mandated administrative rules in cost differentials between the public and private sectors. These rules are often used to achieve additional objectives. If a privatized activity is no longer bound by the same administrative rules, those objectives may be ignored.

An additional area of concern is the oversight role of government after privatization. In Michigan, a private highway maintenance contract resulted in the filling of nonexistent potholes (Schmid 2000). This means that we will have to redesign government institutions from the role of provider of a good or service to a monitor. The two functions require completely different organizational structures and personnel qualifications (Jones, Stallmann, and Infanger 2000).

Once again, the private sector provides some useful comparisons. Corporations in the 1980s used downsizing, spinning off components, and outsourcing-private versions of devolution. Looking at what was, and was not, successful for the private sector may be a useful starting point. In fact, many firms have not seen the cost savings that they expected to gain from downsizing. While the private sector comparison is useful, we have to keep in mind that the private sector's objective is different from that of the government and be careful not to take the analogy too far.

\section{TIME}

Once a privatization decision has been made, there is a transition period. It is important to look at the incentive system that the transition creates for both the private and public sectors. This is a time when old institutions are being destroyed and new institutions are being created and there is a vacuum because it 
is not clear which set of rules applies. Or it is possible that a set of rules is needed just for the transition. Economists tend to assume instantaneous adjustments and, therefore, to ignore the incentives created in the short run as the transition takes place.

When privatizing publicly owned assets or enterprises, we are often talking about large investments. Thus, the number of potential bidders is small and they probably are economically and politically powerful individuals or firms. The small number of potential bidders leads to a less than competitive market for the bidding. The public official can easily make contact with each bidder for solicitation purposes. Because the investment is large, the economic benefit or the influence the pubic official can gain by controlling the outcome is potentially large. For the private sector, the potential gain in wealth is so large that a bribe may be a relatively small cost compared with the potential gain. This may especially be true if the potential gain includes a much lower price for the asset in question. In addition, the sale of an asset is a one-time event. While there may be questions at the time, there is little chance for ongoing review.

While working in other countries last year, I heard allegations that stateowned companies were being sold to friends of the president and that the terms of the sale were not being honored. I have not looked into these in detail, but at the time I attributed it to a long history of corruption (Celarier 1997). Germany, on the other hand, had the reputation of being one of the least corrupt governments. But the amount of public assets available for privatization after reunification was phenomenal. The potential for private gain was enormous, as was the potential for political gain to the party in power. The potential for gain on both sides was so large that existing "controls" were overwhelmed by the short-run incentives. Interestingly, there are currently no allegations that Helmut Kohl personally profited, but rather that the intent was to increase the power of his party (New York Times 2000).

The most descriptive example of this transition period is that of the former Soviet Union. There are innumerable stories of corruption. The transition was much greater for the former Soviet Union than, for example, the Eastern European countries because it had no capitalist history, a very centralized government, and few institutions in place as safeguards (Celarier 1997). The development of the necessary institutions may have been slowed by citizen distrust of government and also by the lack of understanding among the citizenry of the role of government in a market economy (Jones, Stallmann, and Infanger 2000).

There was major privatization in the United Kingdom during the Thatcher administration. Interestingly, I have not found allegations of corruption. (Perhaps I have not looked hard enough.) What were the economic and political circumstances and what institutions were in place during that transition?

In the U.S. we have the famous defense procurement stories. In the last five years, Texas has dealt with corruption in its procurement of food for prisons and in the management of its lottery. On the other hand, it appears that Texas has successfully contracted out some data management activities (Texas Comptroller of Public Accounts 1999). 
Even in a fairly straightforward case, such as deconcentration in Canada, safeguards are needed to guard against corruption. How is the new location determined? Who oversees the process for contracting the construction and the movement of people? Even regular relocations, such as the Olympic Games, can result in corruption if the controls are not in place or if management chooses to ignore them.

While the sale of assets or an enterprise is a one-time event, privatizing operations offers the option of rebidding over time. If bids are used and it is a recurring process with a large number of firms, there is less chance for corruption in both the public and private sectors. If privatization is done without bid, or renewed without bids, there are two problems. First, the provider does not have an incentive to design a low-cost operation. Second, the provider becomes one step removed from public control, so that maintaining cost and quality control may be difficult. The Scandinavian countries provide many public services through nonprofits, without bidding, and are facing a problem with the costs of those services (Stallmann 1998).

Is it possible to come up with a set of predictors of situations that breed corruption, or that breed cost overruns (not directly corruption), or that lead to higher or lower quality service? What institutional safeguards most effectively protect the public interest?

The issue of whether or not there is corruption points out that how we start will affect where we end up, that is, path dependency (Johnson 1994). The path does not have to be smooth. It may be possible to make "corrections" along two of the axes, but it is not possible to go back in time. In addition, the person or firm that controls the asset gains power, making "corrections" more difficult.

The whole issue of transition is not a strong point for economists. Economists tend to assume instantaneous adjustment even when dealing with concepts that are inherently time dependent, such as multipliers. There are some dynamic regional models, but even then an adjustment time or path is usually assumed. Economists have not traditionally investigated transitions. Sociologists have a much stronger tradition of investigating what happens to people or to a community over time (Freudenburg 1992, is an example). Political science, with its concern for process, also has paid more attention to what happens during the process of transition than has economics (Celarier 1997; Donahue 1997).

\section{IMPLICATIONS FOR SOUTHERN STATES AND COMMUNITIES}

The southern states have a history of advocating states' rights. In the South, there has always been support for decentralization of federal government activities to the states. Interestingly, "states' rights" in the South has meant precisely that-the state's, not necessarily local government's or people's, rights. The southern states have some of the more centralized governments, whereas the western states have more power vested at the local level (Zimmerman 1981). Western states were the first to grant initiative and referendum powers to the people. Only seven states east of the Mississippi grant initiative powers, and only 
seven states west of the Mississippi do not (Luttbeg 1999). The northeastern states also have a local control tradition through town hall meetings. Ironically, then, the southern states may be less institutionally equipped to handle decentralization as it moves from the state to the local level. It will require new legislation and may require constitutional changes in some states because many southern states fall under the Dillon rule--powers not granted expressly to the local government are reserved to the state. The other alternative for a state constitution is that powers not directly granted to the state reside with local government; this results in more local control (Gibson and Robison 1995). Further information is needed on the impacts of local control versus state control on the costs, quality, and effectiveness of programs.

While not specific to the South, because it affects all rural areas, an important issue is the ability of local governments to handle decentralization and privatization. Rural elected officials are less educated, are part-time volunteers, have few professional staff, are less connected to information sources, and have tighter budgets than their urban counterparts (Waltzer, Russo, and Gump 1986; Sokolow 1984; Cigler 1993; Garkovich and Irby 1998). Local governments are familiar with basic contracting, but may find the more complex issues of privatization difficult to handle (Jurison 1999; Garkovich and Irby 1998). In addition, rural governments already find it difficult to effectively participate in many state grant programs, one form of decentralization (Reed and Paulsen 1990; Garkovich and Irby 1998). At the same time, decentralization, with its emphasis on grassroots initiatives, will put the onus on communities to seek local solutions to local problems. As regional scientists we may be able to provide local governments with training and analysis (Garkovich and Irby 1998).

\section{SUMMARY}

Devolution is an institutional issue. But the need for specific institutions is better understood by examining the different factors within devolution-privatization, decentralization, and transition. Each of these points out specific institutional changes and institutional needs. These three factors can also be used to delineate a series of research questions for regional scientists.

Devolution has a spatial component. As regional scientists we are uniquely qualified to address issues with a spatial component. But to our spatial analysis we will have to add time and institutions. To do that we will need to add to our toolbox. Sociologists have a tradition of looking at how people and communities adjust to change. Political scientists have examined the performance of different levels of government. Institutional economists address how institutions create incentives for behavior.

Devolution will present some challenges. Perhaps the biggest challenge may be data. At the same time we can also look at the opportunities that this change presents. There are opportunities for quasi-experimental research to compare different programs. So we will need to add some quasi-experimental 
methods to our toolbox. States and local governments are going to need help on data issues: what should be measured, how to define concepts to be measured, how to measure. Small communities will need analytical assistance and training to adjust to the new environment-public management, analysis of alternatives for privatization or decentralization, etc. Those of us in extension may find that our telephones never stop ringing.

Carol Taylor West, in her presidential address, said that the SRSA "has a tradition of presidential addresses that add a new perspective from a different field, from a different background" $(1997$, p. 6). As regional scientists we will need to draw on the fields of public finance, political science, public administration, institutional economics, sociology, and quasi-experimental design to address issues raised by devolution. But as regional scientists we also bring some unique skills to the table that other disciplines can draw on. We have a promising research agenda, if we choose to address it.

\section{"The states are 'laboratories of democracy.'" Justice Louis Brandeis}

\section{REFERENCES}

Barsness, Zoe I., and Kristina A. Deikmann. "Out of Sight, Out of Mind? The Impact of Remote Work Arrangements on Selection and Effectiveness of Feedback Seeking and Impression Management Behaviors." Submitted for review, Academy of Management Journal, 1999.

Brown, David L., and Nina L. Glasgow. "Capacity Building and Rural Government Adaptation to Population Change." In Cornelia B. Flora and James A. Christenson (eds.) Rural Policies for the 1990s. Boulder, CO: Westview Press, 1991.

Celarier, Michelle. "Privatization: A Case Study in Corruption." Journal of International Affairs 50 (1997), 531-543.

Chi, Keon. "Privatization Activities in State Governments." Spectrum 71 (1998), 8-15.

Cigler, Beverly A. "Meeting the Growing Challenges of Rural Local Governments." Rural Development Perspectives 9 (1993), 35-39.

Cook, Thomas D., and Donald T. Campbell. Quasi-Experimentation: Design and Analysis Issues for Field Settings. Dallas: Houghton Mifflin Company, 1979.

Deller, Steve C. "Local Government Structure, Devolution, and Privatization." Review of Agricultural Economics 20 (1998), 135-154.

Dion, Stephane. "A Federation in Evolution: Experts' Perspectives." Le Devoir (1995), A9.

Donahue, John D. "The Devil in Devolution." American Prospect 32 (1997), 42-47. Feldman, Dan. "Privatization Shift in Highway Work Could Cost Millions." Houston Chronicle. 28 November 1999, p. 1A. 
Freudenburg, W.R. "Addictive Economies: Extractive Industries and Vulnerable Localities in a Changing World Economy." Rural Sociology 57 (1992), 305-332. Garkovich, Lori, and Jon Irby. "Where the Rubber Meets the Road: New Governance Issues in America's Rural Communities." Rural Community Consortium. Southern Rural Development Center, Mississippi State, 1998.

Gibson, L. Tucker, and Clay Robison. Government and Politics in the Lone Star State: Theory and Practice. 2d ed. Englewood Cliffs, NJ: Prentice Hall, 1995.

Gromley, William T., Jr. "Privatization Revisited." Policy Studies Review 13 (1995), 215-234.

Haveman, Robert H. Policy and Poverty Research: The Great Society and the Social Sciences. Madison, WI: The University of Wisconsin Press, 1987.

Hirsch, Werner Z. Law and Economics: An Introductory Analysis. New York: Academic Press, 1979.

Johnson, Thomas G. "The Dimensions of Regional Economic Development Theory." The Review of Regional Studies 24 (1994), 119-126.

Jones, Eluned, Judith I. Stallmann, and Craig Infanger. "Free Markets at a Price." Choices (First Quarter 2000), 36-40.

Jurison, Alfred C. "Is Privatization the Answer?" Journal of Housing and Community Development 56 (1999), 6-7.

Luttbeg, Norman R. Comparing the States and Communities: Politics, Government, and Policy in the United States. Dubuque, IA: Eddie Bowers Publishing, Inc., 1999.

Miranda, Rowan, and Allan Lerner. "Bureaucracy, Organizational Redundancy, and the Privatization of Public Services." Public Administration Review 55 (1995), 193-200.

Nelson, Glenn, and Curtis Braschler. "Nonmetropolitan and Metropolitan Medicare Enrollments and Payments." RUPRI Data Report P95-7. Columbia, MO: University of Missouri Rural Policy Research Institute, September 1995.

New York Times. "Kohl's Party Fined \$21 Million." 16 February 2000, p. 15A.

Oates, Wallace E. "An Essay on Fiscal Federalism."Journal of Economic Literature 37 (1999), 1120-1149.

Reed, B.J., and David F. Paulsen. "Small Towns Lack Capacity for Successful Development Efforts." Rural Development Perspectives 6 (1990), 26-30.

Reinschmiedt, Lynn, Mark Henry, Bruce Weber, Elizabeth E. Davis, and Willis Lewis. "Welfare and Food Stamps Caseloads in Three States: Rural-Urban Contrasts." RUPRI Report P99-100. Columbia, MO: University of Missouri Rural Policy Research Institute, December 1999.

Schmid, A. Alan. E-mail to author. University Distinguished Professor, Department of Agricultural Economics, Michigan State University, East Lansing, Michigan, 3 January 2000.

Sokolow, Alvin D. "The Elected Official as Expert: Governing Boards in Rural Communities." Rural Development Perspectives 1 (1984), 4-9. 
Stallmann, Judith I. "The Importance of the Service Sector for Development in Rural Parts in the Nordic Countries: A Discussion." North American Regional Science Association Meeting. Santa Fe, New Mexico, November 11-14, 1998.

Stiglitz, Joseph E. Economics of the Public Sector. $2 \mathrm{~d}$ ed. New York: W.W. Norton \& Company, 1998.

Texas Comptroller of Public Accounts. "Saving Information, Saving Money." Fiscal Notes (November 1999), 10-11.

U.S. Department of Health, Education, and Welfare. The Rural Income Maintenance Experiment, Summary Report. SR10. Washington, D.C., November 1976.

Walton, Marsha, and Robert A. Kraushaar. "Ideas and Information: The Changing Role of States in Economic Development." Economic Development Quarterly 4 (1990), 276-286.

Waltzer, Herbert, Philip A. Russo, and W. Robert Gump. "Professional Networks and Local Officials: A Missing Link in Small Government Management." Rural Development Perspectives 2 (1986), 35-39.

West, Carol T. "Lessons From the Glass Ceiling and the Black Box. Presidential Address to the Southern Regional Science Association." The Review of Regional Studies 27 (1997), 1-8.

Zimmerman, Joseph F. "Measuring Local Government Discretionary Authority." Report M-131. Washington, D.C.: United States Advisory Commission on Intergovernmental Relations, 1981. 
